\title{
Ammonia-oxidizing archaea and bacteria are structured by geography in biological soil crusts across North American arid lands
}

\author{
Yevgeniy Marusenko', Scott T Bates², Ian Anderson', Shannon L Johnson ${ }^{3}$, Tanya Soule ${ }^{4}$ and Ferran Garcia-Pichel ${ }^{\text {* }^{*}}$
}

\begin{abstract}
Introduction: Biological soil crusts (BSCs) can dominate surface cover in dry lands worldwide, playing an integral role in arid land biogeochemistry, particularly in N fertilization through fixation and cycling. Nitrification is a characteristic and universal $\mathrm{N}$ transformation in BSCs that becomes important for the export of $\mathrm{N}$ beyond the microscopic bounds of the crust itself. The contribution of ammonia-oxidizing bacteria (AOB) in BSCs has been shown, but the role and extent of the recently discovered ammonia-oxidizing archaea (AOA) have not.
\end{abstract}

Methods: We sampled various types of crusts in four desert regions across the western United States and characterized the composition and size of ammonia-oxidizing communities using clone libraries and quantitative PCR targeting the amoA gene, which codes for the ammonia monooxygenase enzyme, universally present in ammonia-oxidizing microbes.

Results: All archaeal amoA sequences retrieved from BSCs belonged to the Thaumarchaeota (Nitrososphaera associated Group I.1b). Sequences from the Sonoran Desert, Colorado Plateau, and Great Basin were indistinguishable from each other but distinct from those of the Chihuahuan Desert. Based on amoA gene abundances, archaeal and bacterial ammonia oxidizers were ubiquitous in our survey, but the ratios of archaeal to bacterial ammonia oxidizers shifted from bacterially dominated in northern, cooler deserts to archaeally dominated in southern, warmer deserts.

Conclusions: Archaea are shown to be potentially important biogeochemical agents of biological soil crust $\mathrm{N}$ cycling. Conditions associated with different types of BSCs and biogeographical factors reveal a niche differentiation between $A O A$ and $A O B$, possibly driven by temperature.

Keywords: Biological soil crust, Desert, Arid, amoA, Ammonia oxidation, Nitrification, Nitrogen cycle, Thaumarchaeota

\section{Introduction}

Plant inter-spaces in arid lands are typically colonized by biological soil crusts (BSCs), which in some areas can cover large portions of the landscape (Belnap 1995; Pointing and Belnap 2012). Pioneering cyanobacteria, such as Microcoleus vaginatus, initiate the formation of BSCs by stabilizing loose soils (Garcia-Pichel and Wojciechowski 2009), allowing a succession that involves other bacteria (Garcia-Pichel et al. 2001; Gundlapally and Garcia-Pichel

\footnotetext{
* Correspondence: ferran@asu.edu

${ }^{1}$ School of Life Sciences, Arizona State University, P.O. Box 874501, Tempe, AZ 85287-4501, USA

Full list of author information is available at the end of the article
}

2006; Nagy et al. 2005), archaea (Soule et al. 2009), and fungi (Bates and Garcia-Pichel 2009; Bates et al. 2012), as well as lichens and mosses in well-developed crusts (Belnap and Lange 2003). Functional roles for the majority of nonphototrophic microbes inhabiting BSCs are not known, however, and remain to be established experimentally.

BSC topsoil assemblages are considered "mantles of fertility" (Garcia-Pichel et al. 2003) as they play important roles in biogeochemical processes within arid ecosystems (Belnap and Lange 2003; Evans and Johansen 1999; Strauss et al. 2012), fixing an estimated 0.1 Pg of C and $10 \mathrm{Tg}$ of $\mathrm{N}$ annually across the globe (Elbert et al. 2012). Nitrification (with ammonia oxidation as its rate- 
limiting step) mediated by BSC microbes is another important component of arid land nutrient cycling that directly impacts soil fertility and rivals $\mathrm{N}$-fixation in its magnitude (Johnson et al. 2005). Nitrifiers, such as Nitrosospira, have been recovered from BSCs in molecular surveys, and most probable number assessments suggest ammonia-oxidizing bacteria $(\mathrm{AOB})$ are numerically abundant in BSCs (Gundlapally and Garcia-Pichel 2006; Johnson et al. 2005). Although archaea are likely important soil ammonia oxidizers (Leininger et al. 2006; Zhang et al. 2010; Bates et al. 2011; Stahl and de la Torre 2012) and sizable archaeal populations have been reported from BSCs (Soule et al. 2009), little is known about the role of archaea in the arid land N-cycle.

Recent research has improved our understanding of factors that drive the dynamics between archaeal and bacterial ammonia oxidizers in soils. For example, alkaline soils and lower $\mathrm{NH}_{4}^{+}$concentrations may favor some ammonia-oxidizing archaea (AOA) over their bacterial counterparts (Gubry-Rangin et al. 2011; Martens-Habbena et al. 2009). Although desert soils are typically characterized by these conditions, few studies have specifically examined AOA in BSCs or the factors that structure communities of $\mathrm{N}$-cycling microbes in arid lands (e.g., Johnson et al. 2005, 2007; Marusenko et al. 2013). As approximately one-third of the terrestrial surface is arid or semi-arid land, and BSC cover can be substantial, understanding the dynamics of nitrification mediated by crust microbes has relevance to the global N-cycle.
Considering the potential for archaea to play an important role in arid land nitrification as ammonia oxidizers, we assessed the diversity and abundance of archaeal amo $A$ genes in BSCs within four biogeographically distinct deserts in the western United States. For comparison, we quantified the abundance of bacterial $a m o A$ genes and estimated the portion of $\mathrm{AOA}$ and $\mathrm{AOB}$ in these $\mathrm{BSC}$ microbial communities using published determinations of archaeal 16S rRNA genes from the same samples (Soule et al. 2009). We also examined the role of environmental factors, particularly those associated with latitudinal gradients, in structuring these communities of crust ammonia oxidizers.

\section{Methods}

\section{Sampling and DNA extraction}

We sampled different crust types (e.g., those dominated by cyanobacteria, lichen, or moss) in a variety of geographically dispersed sites (Figure 1, Additional file 1) across four distinct desert systems in the western United States, including the Great Basin, Colorado Plateau, Chihuahuan Desert, and Sonoran Desert (listed in order of increasing temperature; Belnap and Lange 2003). The mean annual temperature across the four desert regions sampled ranged from $4{ }^{\circ} \mathrm{C}$ to $22^{\circ} \mathrm{C}$. These crust samples were previously characterized for archaeal diversity (Soule et al. 2009) based on 16S rRNA genes. For sampling, the bottom portion of a $55 \mathrm{~mm}$ Petri plate was used to excise a circular portion of the crust matrix (to a

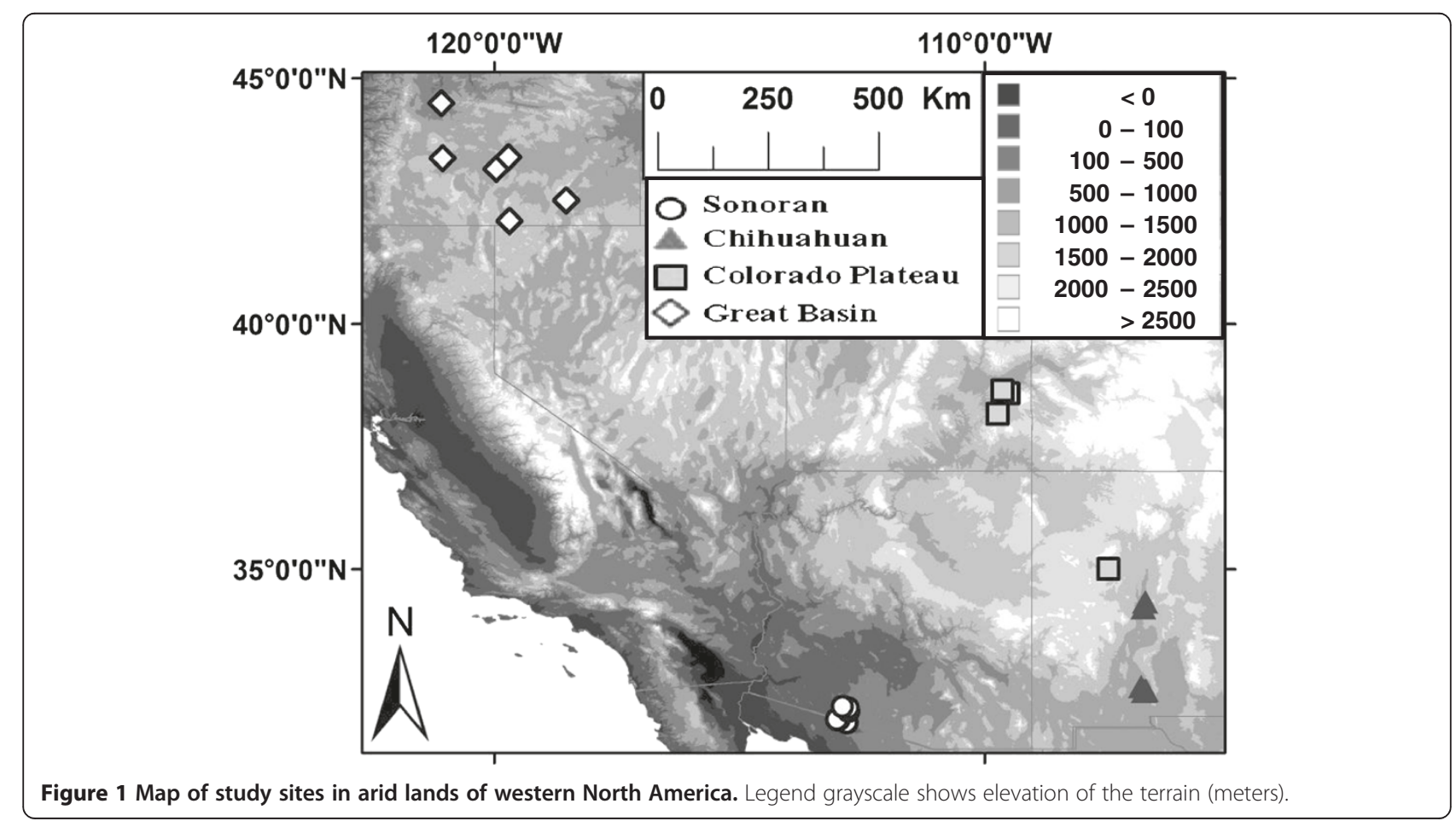


depth of $\sim 1 \mathrm{~cm}$ ) after wetting with a mist of sterile ultra-pure milli-Q water in order to make the crust supple to facilitate collection. All samples were allowed to air-dry, given a unique identification number, sealed in Zip-lock plastic bags for transport, and then stored dry in the lab's repository at room temperature, as recommended for arid land soil samples (Campbell et al. 2009), until DNA extraction. Approximately $1 \mathrm{~g}$ of the crust matrix was aseptically transferred to microcentrifuge vials of the Ultra Clean Soil DNA Isolation Kit (MoBio Laboratories, Carlsbad, CA, USA), and standard protocols were used in DNA extraction following the kit instructions. All extracts were stored at $-80^{\circ} \mathrm{C}$ until use in downstream applications.

\section{Clone libraries and phylogeny of amo $A$ genes}

Clones were obtained from PCR products of community DNA using the amoA primers (position 4-23 and 619-638) and protocol described by Francis et al. (2005). Primers designed to hybridize at the ends of the $a m o A$ gene are good options for general assays and have been successfully used for soils (Chen et al. 2008; Mao et al. 2011; Nicol and Prosser 2011). One clone library was constructed for each desert region by pooling extracts from at least 10 individual sites. All PCR products were checked for quality against an EZ Load Precision Molecular Mass Ruler (Bio-Rad Laboratories, Hercules, CA, USA) on $1 \%$ agarose gels (with a TAE buffer base) by standard gel electrophoresis, followed by ethidium bromide staining and imaging using the Fluor-S MultiImager system (Bio-Rad Laboratories). Products were then purified for ligation using the QIAquick PCR Purification Kit (Qiagen Sample and Assay Technologies, Valencia, CA, USA) prior to constructing the libraries using the TOPO TA Cloning Kit (Invitrogen, Carlsbad, CA, USA) in accordance with the manufacturer's specifications. Cloning and transformation success were verified through PCR with $1 \mu \mathrm{l}$ of clone-containing media as the template DNA. The clones obtained were then sequenced in the forward and reverse directions at a commercial laboratory.

Phylogenetic analyses were carried out on a single alignment file that included $a m o A$ gene sequences from our clone libraries (one representative sequence from each $a m o A$ phylotype that was recovered from the four deserts) as well as reference groups of AOA retrieved from GenBank and originating from previous studies (Venter et al. 2004; Konneke et al. 2005; Hallam et al. 2006; Hatzenpichler et al. 2008; de la Torre et al. 2008; Walker et al. 2010; Park et al. 2010; Tourna et al. 2011; Matsutani et al. 2011; Jung et al. 2011; Blainey et al. 2011; Lehtovirta-Morley et al. 2011; Santoro and Casciotti 2011; French et al. 2012; Mosier et al. 2012). Additionally we included 3,619 high-quality sequences from the Dryad data repository (see sequence quality filtering by Fernandez-Guerra and Casamayor 2012a). All sequences were combined and realigned using MAFFT (Katoh et al. 2002) and analyzed with the phylogenetic tree building module of the MEGA 5 software package with the following parameters: neighbor-joining statistical method, Jukes-Cantor nucleotide substitution model, bootstrapping for 100 replicates, uniform rates, and complete deletion of gaps/missing data (Tamura et al. 2011). Representative sequences of novel archaeal $a m o A$ genes from each of the deserts have been submitted to GenBank (NCBI accession numbers: Sonoran, EU439775; Great Basin, EU439776; Colorado Plateau, EU439777; Chihuahuan, EU439778).

\section{Quantitative PCR of archaeal and bacterial amoA genes}

For use in quantitative PCR (qPCR), we developed archaeal-specific amo $A$ primers based on sequences obtained from our clone library work (those known to be present in our BSC samples) as well as those available in public databases. These primers, amoA310f (5' -TGGAT ACCBTCWGCAATG-3') and amoA529r (5'-GCAACM GGACTATTGTAGAA-3'), were designed to yield PCR products of approximately $220 \mathrm{bp}$, of optimal length for qPCR. This primer set was then used for qPCR in $20 \mu \mathrm{l}$ reactions that contained the following: $10 \mu \mathrm{l}$ iTaq SYBR Green Master Mix (Bio-Rad Laboratories), $300 \mathrm{nM}$ amoA310f/amoA529r, and 10 ng of environmental DNA. The reaction conditions had an initial denaturation step of $2.5 \mathrm{~min}$ at $95^{\circ} \mathrm{C}$ followed by 55 cycles of $15 \mathrm{~s}$ at $95^{\circ} \mathrm{C}$ and $1 \mathrm{~min}$ at $54^{\circ} \mathrm{C}$, and a final dissociation step later used to check the fidelity of the qPCR results. For quantification, a standard curve (log-linear $R^{2}>0.97$ ) was generated using a purified, linearized, and quantified archaeal amoA clone plasmid in a dilution series that spanned from $10^{1}$ to $10^{9}$ gene copies per reaction.

Bacterial amo $A$ qPCR was carried out in $20 \mu \mathrm{l}$ reactions using primers amoA-1f and amoA-2r (Rotthauwe et al. 1997) at a final concentration of $500 \mathrm{nM}$, along with $10 \mu \mathrm{l}$ iTaq SYBR Green Master Mix and $10 \mathrm{ng}$ of environmental DNA. The reaction conditions were as follows: initial denaturation for $2.5 \mathrm{~min}$ at $95^{\circ} \mathrm{C}$ followed by 45 cycles of $15 \mathrm{~s}$ at $95^{\circ} \mathrm{C}$ and $1 \mathrm{~min}$ at $55^{\circ} \mathrm{C}$, and a final dissociation step. A standard curve for quantification (log-linear $R^{2}>0.95$ ) was generated using genomic DNA from Nitrosomonas europaea ATCC 19718 (Chain et al. 2003) in a dilution series that spanned from $10^{1}$ to $10^{9}$ gene copies per reaction.

Multiple measures were taken to ensure quality qPCR data. All reactions for both archaeal and bacterial amo $A$ qPCR runs were carried out in triplicate to account for analytical variability. Triplicates were averaged prior to any data calculations reported in the results. Melting curves obtained in the denaturation step were visually inspected to verify the quality of each reaction and to 
insure the absence of primer-dimers. Reported results contain only determinations for which $C_{t}$ values could be interpolated within our standard curves, and failed or suspect reactions (those with questionable melting curves) were excluded from the data set.

\section{Data analyses}

We downloaded environmental data from the Commission for Environmental Cooperation for elevation and climate (years 1950-2000; CEC, http://www.cec.org) and used ArcGIS version 10.1 to extract exact values (for environmental data) corresponding to coordinates from the sites used in this study (Additional file 1). Canonical correspondence analysis (CCA; Ter Braak 1986; Palmer 1993) was used in the Palaeontological Statistics (PAST; Hammer et al. 2001; Fu et al. 2006) software package to explore associations between environmental factors [e.g., mean annual temperature (MAT) and mean annual precipitation (MAP)] and the dependent variables. The three dependent variables used were amoA gene abundances (archaeal, bacterial) and the archaeal to bacterial amoA ratio.

Statistical tests were carried out using SPSS (version 20.0 for Windows). Linear model assumptions were tested using Shapiro-Wilk and SPSS normal probability plots (for normality) and Levene's test (for homoscedasticity), and data were transformed (natural log) when necessary. Bivariate Pearson correlation and linear regression analyses were performed to assess significance of relationships between $a m o A$ data and environmental factors throughout the four desert regions (Hocking 1976). Significant differences of regression slopes across environmental gradients in replicated data for gene copy numbers were analyzed as a multiple linear regression (multiple dependent variables, one independent variable). Due to co-correlation of external factors (latitude positively correlated with elevation and MAP, and negatively with MAT), regressions were carried out separately for each independent variable to assess the potential effect of each variable without being able to interpret the combined effects of multiple variables (Smith et al. 2009). The sets of dependent variables were archaeal $a m o A$, bacterial $a m o A$, ratio of archaeal to bacterial $a m o A$, separately for the simple linear regression, and archaeal $a m o A$ vs. bacterial $a m o A$ in the multiple regression.

\section{Results}

Diversity and phylogeny of archaeal amoA genes of BSCs To obtain a geographically integrated survey of the diversity in archaeal amoA genes, we analyzed clone libraries representing each of the four distinct desert systems across the western U.S. (Chihuahuan, Great Basin, Colorado Plateau, and Sonoran). Analysis of clone libraries, with more than 40 clones in each desert, revealed that monophyletic amoA gene populations corresponding to each desert region exist in arid land BSCs: only a single archaeal amoA phylotype was recovered from each desert (98.5-100\% nucleotide similarity). Phylogeny (Figure 2) of the four representative sequences revealed that phylotypes from three of the deserts (Great Basin, Sonoran, and Colorado Plateau) were indistinguishable, grouping in a well-defined clade ( $>95 \%$ similarity, $76 \%$ bootstrap support), while a lone sequence type (representing the Chihuahuan Desert) was distinct (only $81 \%$ similarity to other amoA gene sequences obtained from BSCs). All four phylotypes, however, are part of the Group I.1b Nitrososphaera cluster as identified by Pester et al. (2012). The Chihuahuan Desert sequence grouped near sequences representing Nitrososphaera subcluster 2, closely related to the amoA gene of $N$. viennensis (Tourna et al. 2011; the only pure thaumarchaeotal isolate from soil), while the other three desert phylotypes were most closely related to Nitrososphaera subclusters 6 and 11.

Abundance of archaeal and bacterial $a m o A$ genes of BSCs Population densities of putative ammonia oxidizers were assayed through qPCR of $a m o A$ genes from the four arid regions. Archaeal amoA copy numbers average around $7 \times 10^{5}$ per gram of soil (332 copies per ng DNA) across all desert sites (Table 1), whereas their bacterial counterparts averaged only slightly (and nonsignificantly) below this value at $3 \times 10^{5}$ (154 copies per ng DNA). The sizes of the AOA populations in BSCs were more variable than those of $\mathrm{AOB}$, with densities of archaeal $a m o A$ genes ranging over three orders of magnitude in individual sites within each desert (ca. five orders of magnitude across all deserts), and bacterial $a m o A$ genes ranging over only one to two orders of magnitude (ca. three orders of magnitude across all deserts). More notably, the average of the ratios for archaeal to bacterial amoA gene copy number for each desert (Table 2) were highest in the southernmost, warmer deserts (54.7 and 3.5 for Sonoran and Chihuahuan, respectively) as compared to the cold deserts of more northern latitudes (1.3 and 0.01 for Colorado Plateau and Great Basin, respectively).

CCA revealed patterns between environmental factors and ammonia oxidizers across geographical provinces encompassed by the survey (trace $p$ value $<0.01$; Figure 3). Generally, the Sonoran Desert sites are associated with higher MAT, while those of the Great Basin and Colorado Plateau sites are more positively associated with elevation and MAP. Conditions associated with lower latitudes in our dataset (i.e., higher temperatures, lower elevation, lower precipitation) were negatively related to the size of the bacterial $a m o A$ population and positively related to both archaeal $a m o A$ and the ratio of archaeal to bacterial amoA. 


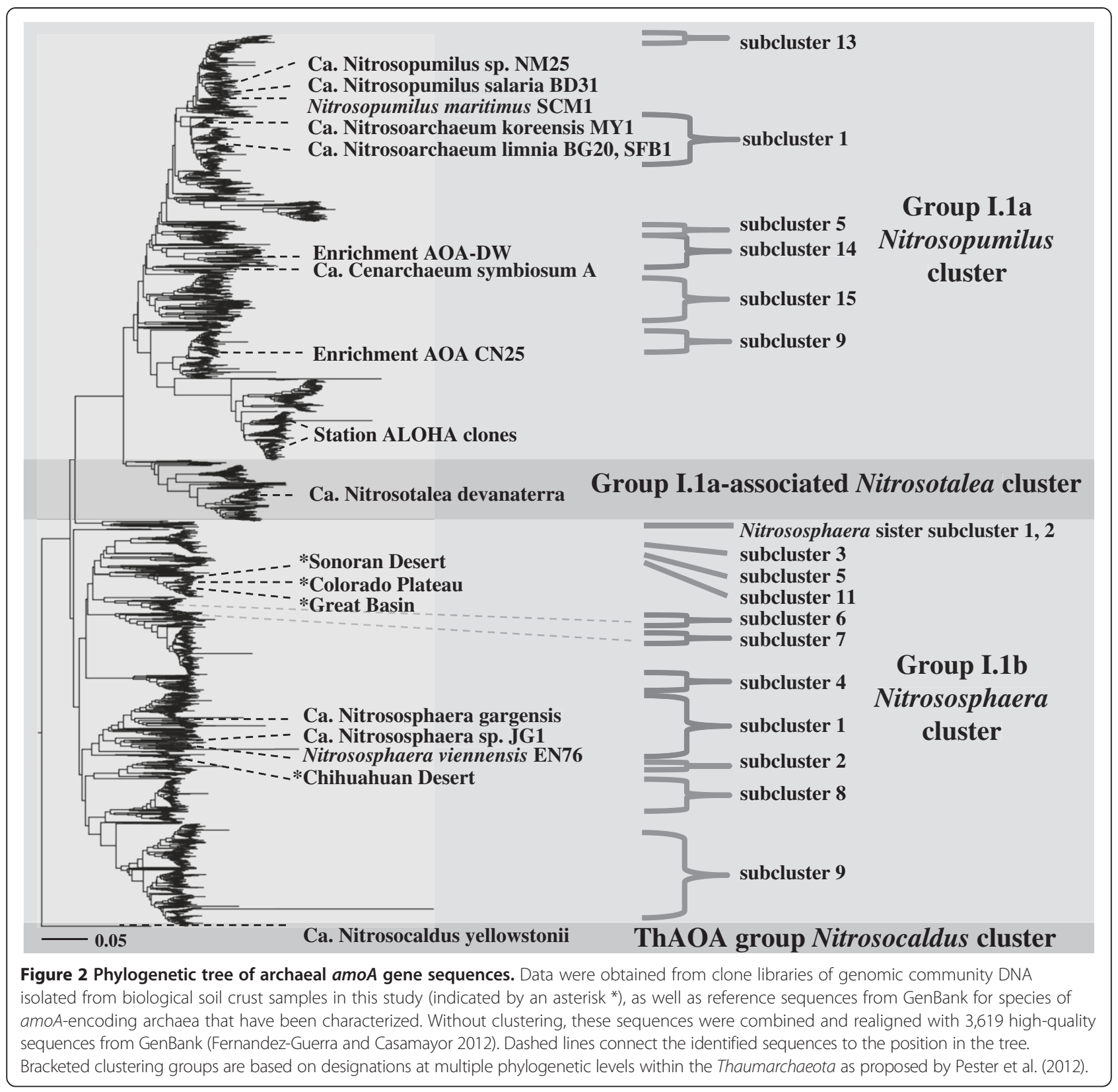

Table 1 Population densities of ammonia-oxidizing microbes in biological soil crusts estimated by qPCR of amoA genes

\begin{tabular}{|c|c|c|c|c|}
\hline \multirow[b]{2}{*}{ Province } & \multicolumn{2}{|l|}{ Archaeal $^{a} a m o A$} & \multicolumn{2}{|l|}{ Bacterial $^{b} a m o A$} \\
\hline & Range & Average ( $\pm \mathrm{SD})$ & Range & Average $( \pm S D)$ \\
\hline Sonoran & $2.8 \times 10^{3}-5.5 \times 10^{6}$ & $0.75 \pm 1.6 \times 10^{6}$ & $3.9 \times 10^{3}-3.7 \times 10^{5}$ & $0.47 \pm 1.0 \times 10^{5}$ \\
\hline Chihuahuan & $1.5 \times 10^{3}-6.7 \times 10^{6}$ & $1.1 \pm 2.0 \times 10^{6}$ & $8.7 \times 10^{4}-5.0 \times 10^{5}$ & $2.5 \pm 1.9 \times 10^{5}$ \\
\hline Colorado Plateau & $2.0 \times 10^{3}-5.8 \times 10^{6}$ & $0.59 \pm 1.8 \times 10^{6}$ & $9.2 \times 10^{4}-5.9 \times 10^{5}$ & $3.4 \pm 1.6 \times 10^{5}$ \\
\hline Great Basin & $5.4 \times 10^{1}-4.8 \times 10^{4}$ & $1.7 \pm 2.3 \times 10^{4}$ & $2.2 \times 10^{4}-5.0 \times 10^{6}$ & $1.1 \pm 2.0 \times 10^{6}$ \\
\hline All deserts & $5.4 \times 10^{1}-6.7 \times 10^{6}$ & $0.69 \pm 1.6 \times 10^{6}$ & $3.9 \times 10^{3}-5.0 \times 10^{6}$ & $3.4 \pm 8.4 \times 10^{5}$ \\
\hline
\end{tabular}

${ }^{a}$ In descending order $n=12,10,11,6,39 .{ }^{b}$ In descending order $n=12,8,12,6,38$. All qPCR data are for amoA gene copies per gram of crusted soil. 
Table 2 Relative densities for ammonia-oxidizing microbial communities in biological soil crusts (amoA or $16 \mathrm{~S}$ genes)

\begin{tabular}{|c|c|c|c|c|}
\hline \multirow[b]{2}{*}{ Province } & \multicolumn{2}{|c|}{ Ratio of archaeal to bacterial ${ }^{a} a m o A$} & \multicolumn{2}{|c|}{ Ratio of archaeal ${ }^{b} a m o A$ to archaeal $16 S^{c}$} \\
\hline & Range & Average $( \pm \mathrm{SD})^{d}$ & Range & Average $( \pm \mathrm{SD})^{d}$ \\
\hline Sonoran & $0.073-257.995$ & $54.733 \pm 83.924$ & $5.0 \times 10^{-5}-1.0 \times 10^{-1}$ & $3.9 \pm 6.8 \times 10^{-2}$ \\
\hline Chihuahuan & $0.020-15.844$ & $3.459 \pm 5.165$ & $6.9 \times 10^{-4}-2.6 \times 10^{-1}$ & $6.8 \pm 9.9 \times 10^{-2}$ \\
\hline Colorado Plateau & $0.003-12.664$ & $1.279 \pm 3.794$ & $2.6 \times 10^{-5}-7.4 \times 10^{-1}$ & $7.4 \pm 23.2 \times 10^{-2}$ \\
\hline Great Basin & $0.003-0.009$ & $0.006 \pm 0.003$ & $9.9 \times 10^{-6}-7.0 \times 10^{-4}$ & $2.5 \pm 3.9 \times 10^{-4}$ \\
\hline All deserts & $0.003-257.995$ & $19.510 \pm 53.405$ & $9.9 \times 10^{-6}-7.4 \times 10^{-1}$ & $5.3 \pm 14.8 \times 10^{-2}$ \\
\hline
\end{tabular}

${ }^{a}$ In descending order $n=11,8,11,3,33 .{ }^{b}$ In descending order $n=9,6,10,3,28 .{ }^{c}$ Determinations for general archaeal 16S rRNA gene copies per gram from Soule et al. 2009. ${ }^{d}$ Average of all ratios for the designated province. All data here are for qPCR determinations of amoA or $16 \mathrm{~S}$ genes as copies per gram of crusted soil.

Correlation and regression approaches clearly confirmed distinct relationships between archaeal and bacterial amoA gene abundances of BSCs and specific environmental factors across the four deserts (Table 3). For example, archaeal amoA abundance was most strongly correlated with latitude $(r=-0.53, p=0.001)$. Bacterial $a m o A$ abundance, on the other hand, was most strongly correlated with elevation $\quad(r=0.78, p<0.001)$. Most revealing were the strong, significant correlations between the archaeal to bacterial amo $A$ gene abundance ratio and a range of environmental factors: latitude, elevation, MAT, and MAP. These relationships translated into the general geographic trend of archaeal amo $A$ gene abundance dominating over that of $\mathrm{AOB}$ in the warmer, more southern deserts, with $\mathrm{AOB}$ dominating in the more northern, colder deserts (Figure 4).

\section{Discussion}

Our results show that archaeal amoA genes are conspicuously and widely represented in BSCs from several arid regions of North America, suggesting that archaea are potentially involved in the process of ammonia oxidation of these soil communities. In general, average AOA abundance in BSCs was 10- to 20-fold lower than in most other types of soils, with some overlap in range (He et al. 2007; Leininger et al. 2006), and less than 10 -fold smaller as reported in few other environments (Chen et al. 2008; Gleeson et al. 2010; Zeglin et al. 2011). Judged by the counts of amoA gene copies, AOA in fact outnumbered AOB when averaged over all sites.

The populations of amoA-bearing archaea are, however, of low diversity based on initial surveying in these systems using clone libraries, which mirrors the findings that archaeal diversity is also generally restricted in both

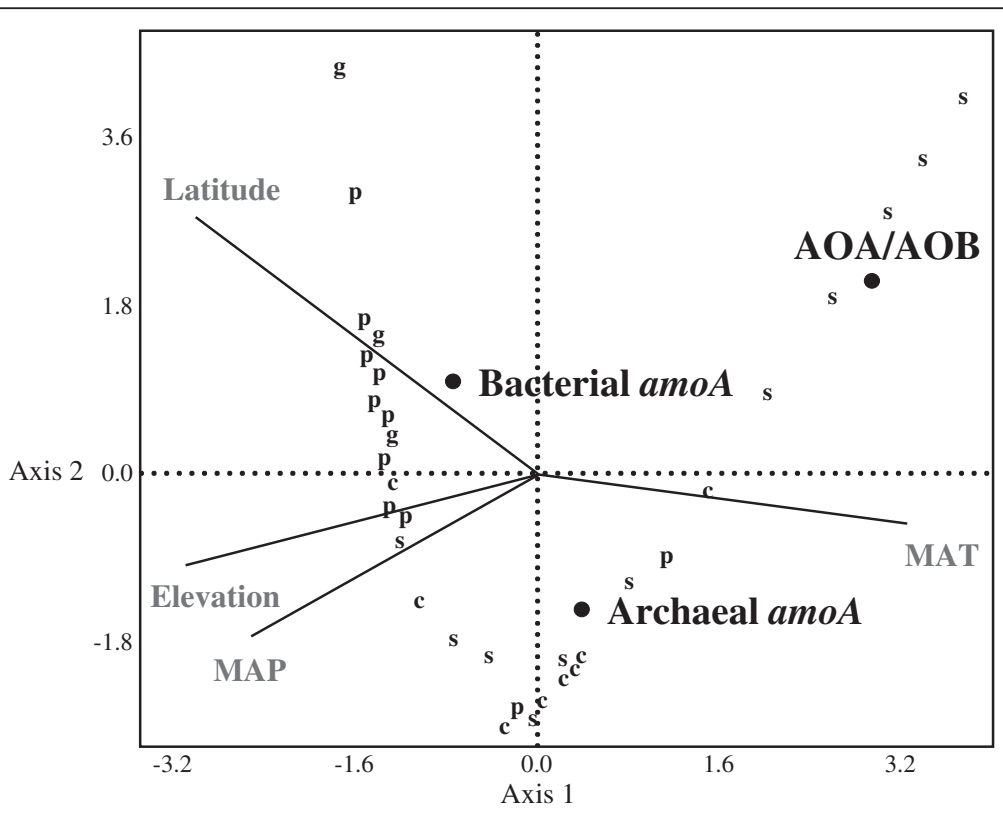

Figure 3 Canonical correspondence analysis (CCA) across all study sites. The dependent variables (ammonia-oxidizing gene abundance and community data) ordinate along a gradient that is driven by vectors related to the independent variables (environmental factors). AOA/AOB, ratio of archaeal to bacterial amoA; MAT, mean annual temperature; MAP, mean annual precipitation; c, Chihuahuan Desert; $p$, Colorado Plateau; $g$, Great Basin; and s, Sonoran Desert. 
Table 3 Results from correlation and multiple linear regression analyses for microbial communities in biological soil crusts

\begin{tabular}{|c|c|c|c|c|c|}
\hline \multirow[b]{2}{*}{$\begin{array}{l}\text { Independent } \\
\text { variable }\end{array}$} & \multicolumn{4}{|c|}{ Bivariate correlation (Pearson $r$ coefficients) } & \multirow{2}{*}{$\begin{array}{l}\text { Regression ( } p \text { values) } \\
\text { Archaeal amo } A \text { vs. bacterial } \\
\text { amo } A\end{array}$} \\
\hline & $\begin{array}{l}\text { Archaeal } a m o A \\
(n=39)\end{array}$ & $\begin{array}{l}\text { Bacterial } a m o A \\
(n=38)\end{array}$ & $\begin{array}{l}\text { Archaeal to bacterial } a m o A \\
(n=33)\end{array}$ & $\begin{array}{l}\text { Archaeal } a m o A \text { to } 16 \mathrm{~S} \\
(n=28)\end{array}$ & \\
\hline Latitude & $-0.53^{* *}$ & $0.40^{*}$ & $-0.70^{* *}$ & $-0.55^{* *}$ & $<0.001$ \\
\hline Elevation & -0.22 & $0.78^{* *}$ & $-0.61^{* *}$ & -0.25 & $<0.001$ \\
\hline MAP & -0.13 & $0.67^{* *}$ & $-0.48^{* *}$ & -0.12 & 0.004 \\
\hline MAT & $0.39^{*}$ & $-0.65^{* *}$ & $0.69^{* *}$ & $0.40^{*}$ & $<0.001$ \\
\hline
\end{tabular}

**Correlation is significant at the 0.01 level. *Correlation is significant at the 0.05 level. MAP, mean annual precipitation; MAP, mean annual temperature.

bulk soils (Auguet et al. 2010; Fernandez-Guerra and Casamayor 2012) and in BSCs (Nagy et al. 2005; Soule et al. 2009). We note that most publicly available sequences that had high similarity ( $>97 \%$ at the nucleotide level) to those of BSCs from this study originated from terrestrial environments with source soils of relatively alkaline character (Leininger et al. 2006; Shen et al. 2008; Zhang et al. 2009, 2011; Liu et al. 2010; Glaser et al. 2010; Fan et al. 2011). Because the number of samples analyzed is not exhaustive, we cannot assert with confidence that the two main amo $A$ phylotypes found in BSCs in this study represent crust-specific lineages, although this remains a possibility to be explored further. Other studies have shown that certain AOA lineages have adapted to specific levels of $\mathrm{pH}$ (GubryRangin et al. 2010, 2011). Arid lands are characteristically extreme environments exposed to intense UV radiation, limited availability of nutrients, alkaline soils, as well as distinct seasonal changes of long desiccation periods punctuated by pulsed precipitation events (Schlesinger 1997; Safriel et al. 2005), all of which may help carve separate niches for soil organisms (Wall and Virginia 1999). AOA dynamics may be distinct and depend on the range of a certain environmental variable (e.g., temperature gradient in only alkaline soils) in different types of BSCs and other local conditions that affect crusts (Garcia-Pichel et al. 2003; Pointing and Belnap 2012). What seems clear is that crust-dwelling AOA are part of a broader consortium of archaea more related to the group I.1b Nitrososphaera cluster than to any other Thaumarchaeota group. All BSC amoA archaeal phylotypes were nested within a larger group that holds the sequence from the only pure culture isolate from soil capable of chemolithoautotrophic ammonia oxidation, Nitrososphaera viennensis (Tourna et al. 2011).

Unexpected patterns of distribution emerged when AOA and $\mathrm{AOB}$ population size was related to geography. Variables that are associated with latitude become important predictors of $a m o A$ abundance. Since an AOA/AOB ratio of $>10$ (accounting for cell sizes, specific growth rates; Prosser and Nicol 2012) suggests archaea outcompete bacteria in ammonia-oxidizing activities, such latitudinal factors likely structure communities and soil function across the dry lands surveyed here. Temperature was positively associated with AOA abundance and with the ratio of $\mathrm{AOA} / \mathrm{AOB}$, in support of other studies showing that $\mathrm{AOA}$ respond preferentially to elevated temperature in enrichment cultures (Kim et al. 2012) and in soil
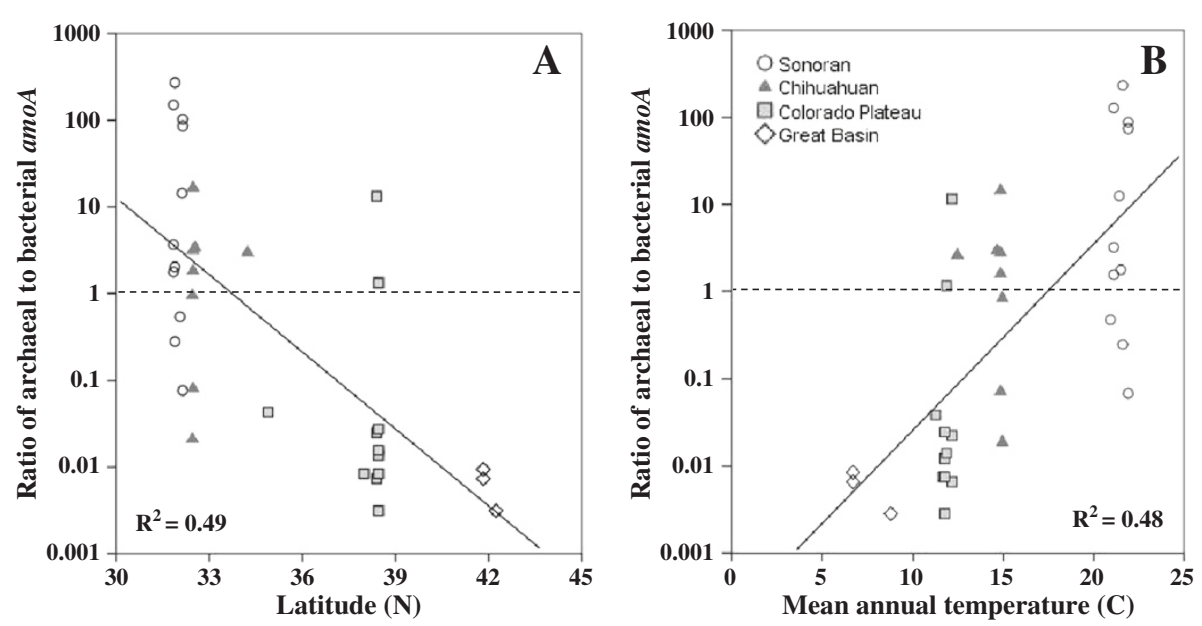

Figure 4 Relationship of archaeal to bacterial $a m o A$ ratio across all geographical locations. Ammonia-oxidizing community is correlated with (A) latitude and (B) mean annual temperature. Dotted line at $y=1$ indicates division between archaeal vs. bacterial amoA dominance. 
microcosms (Tourna et al. 2008), and correlate well with environmental temperature gradients (Bates et al. 2011; Cao et al. 2011), while some studies show negative or no response to temperature (Adair and Schwartz 2008; Jung et al. 2011). Together with our results, these findings suggest that temperature may be an important driver of niche separation for AOA, potentially leading to diverse ecosystem function responses that will depend on the magnitude of temperature change in the environment.

Based on previously reported qPCR determinations of $16 \mathrm{~S}$ rRNA gene copy numbers for archaea from the same sample set (Soule et al. 2009), AOA can account but for a small proportion of the extant total population of BSC archaea. Assuming the number of copies per cell for amoA (1 for archaea, 2.5 for bacteria) and 16S rRNA genes ( 1 for both archaea and bacteria) as can be inferred from known genome studies (Klappenbach et al. 2001; Norton et al. 2002; Hallam et al. 2006; Blainey et al. 2011), putative AOA represent only about $\sim 5 \%$ of the archaeal populations present in BSCs across all deserts and as little as $0.03 \%$ on average for the Great Basin samples. Even when considering possible uncertainties in these estimates stemming from primer bias (Baker et al. 2003; Agoguè et al. 2008), our results are consistent with other soil environments globally (Lehtovirta et al. 2009; Ochsenreiter et al. 2003; Schleper and Nicol 2010). This clearly implies that the bulk of archaeal populations in BSCs (particularly the few dominant crust phylotypes documented by Soule et al. 2009) cannot be identified as AOA, leaving the functional role for the bulk of BSC archaea as undetermined. While archaea are potentially important for nitrification processes in arid lands, AOA must then be found among the rarer, possibly as yet to be detected, members of BSC microbial communities.

\section{Conclusion}

Microbial involvement in regulating the availability of usable forms of $\mathrm{N}$ and controlling productivity in pristine systems is critical for the ecosystem (Schimel and Bennett 2004; van der Heijden et al. 2008; Nannipieri and Eldor 2009). BSCs of arid lands contain Thaumarchaeota that lose dominance to $\mathrm{AOB}$ with increasing latitude, from southern, warmer deserts to northern, colder climates. In some BSCs, AOB outnumber AOA by 100 -fold, which to our knowledge is greater than any current report for soil environments where $\mathrm{AOB}$ dominate (e.g., Di et al. 2009; Hallin et al. 2009; Gleeson et al. 2010), more closely resembling other types of ecosystems and conditions (estuary, Mosier and Francis 2008; wastewater treatment bioreactor, Ye and Zhang 2011). Niche differentiation plays a role amongst $\mathrm{AOA}$ and $\mathrm{AOB}$ communities in general (Gubry-Rangin et al. 2011; Hatzenpichler 2012), and the same may also be true for BSCs. The BSC system can be used in further research to elucidate novel aspects of ammonia oxidation and AOA, such as AOA capacity for mixotrophic growth and the potential for denitrifying ability (Bartossek et al. 2010; Tourna et al. 2011; Xu et al. 2012). For example, phototrophic contributions in surface crusts create unique temporal and spatial gradients of $\mathrm{pH}$, nitrogen, oxygen, and carbon availability (Garcia-Pichel and Belnap 1996; Johnson et al. 2007), which can be used to test AOA response at the microscale as well as across biogeographical regions. Overall, arid lands may provide further insight into environmental drivers of ammonia oxidation and community shifts of ammonia oxidizers, which has important implications for understanding nitrogen cycling at the global scale.

\section{Additional file}

Additional file 1: Origin and type of biological soil crusts used in this study. File describes additional information about each site used in this study. Data include biogeographical province, site ID, and which sites were used for $\mathrm{PPCR}$ determinations (bacterial amoA, archaeal $a m o A$, archaeal $16 \mathrm{~S}$ rRNA), crust type, latitude, longitude, mean annual temperature, and mean annual precipitation.

\section{Abbreviations}

BSC: Biological soil crust; AOA: Ammonia-oxidizing archaea; AOB: Ammonia-oxidizing bacteria; MAT: Mean annual temperature; MAP: Mean annual precipitation.

\section{Competing interests}

The authors declare that they have no competing interests.

\section{Authors' contributions}

IA, SJ, SB, TS, and YM participated in lab bench and/or phylogenetic work. FGP and SB designed the experimental approach. YM, SB, TS and FGP contributed to the drafting of the manuscript. All authors contributed intellectually to the ideas and data interpretations in this work. All authors read and approved the final manuscript.

\section{Acknowledgements}

We thank Moria Nagy and G.S.N. Reddy for sharing their experiences with crust archaea. We are grateful to the staff of Sevilleta and Jornada LTER sites as well as the National Park Service (Canyonlands N.P. and Organ Pipe N.M.) for providing sampling permits, guidance, and hospitality. Finally, we thank Scott Bingham for assistance with GPCR and sequencing. This research was funded by an NSF grant from the Biodiversity Surveys and Inventories Program and by a USDA grant from the Soil Processes Program to FGP.

\section{Author details}

'School of Life Sciences, Arizona State University, P.O. Box 874501, Tempe, AZ 85287-4501, USA. ${ }^{2}$ Cooperative Institute for Research in Environmental Sciences, University of Colorado, Boulder, CO 80309, USA. ${ }^{3}$ Bioscience Division, B-11, Los Alamos National Laboratory, Los Alamos, NM 87545, USA. ${ }^{4}$ Department of Biology, Indiana University-Purdue University, Fort Wayne, IN, USA.

Received: 22 January 2013 Accepted: 7 March 2013 Published: 26 April 2013

\section{References}

Adair KL, Schwartz E (2008) Evidence that ammonia-oxidizing archaea are more abundant than ammonia-oxidizing bacteria in semiarid soils of northern Arizona, USA. Microb Ecol 56(3):420-426

Agogué H, Brink M, Dinasquet J, Herndl GJ (2008) Major gradients in putatively nitrifying and non-nitrifying Archaea in the deep North Atlantic. Nature 456(7223):788-791 
Auguet J, Barberan A, Casamayor EO (2010) Global ecological patterns in uncultured Archaea. ISME J 4(2):182-190

Baker GC, Smith JJ, Cowan DA (2003) Review and re-analysis of domain-specific 165 primers. J Microbiol Methods 55(3):541-555

Bartossek R, Nicol GW, Lanzen A, Klenk H, Schleper C (2010) Homologues of nitrite reductases in ammonia-oxidizing archaea: diversity and genomic context. Environ Microbiol 12(4):1075-1088

Bates ST, Garcia-Pichel F (2009) A culture-independent study of free-living fungi in biological soil crusts of the Colorado Plateau: their diversity and relative contribution to microbial biomass. Environ Microbiol 11(1):56-67

Bates ST, Berg-Lyons D, Caporaso JG, Walters WA, Knight R, Fierer N (2011) Examining the global distribution of dominant archaeal populations in soil. ISME J 5(5):908-917

Bates ST, Nash TH III, Garcia-Pichel F (2012) Patterns of diversity for fungal assemblages of biological soil crusts from the southwestern United States. Mycologia 104(2):353-361

Belnap J (1995) Surface disturbances: their role in accelerating desertification. Environ Monit Assess 37(1-3):39-57

Belnap J, Lange OL (2003) Biological soil crusts: structure, function, and management. Springer Verlag, Berlin, Germany

Blainey PC, Mosier AC, Potanina A, Francis CA, Quake SR (2011) Genome of a low-salinity ammonia-oxidizing archaeon determined by single-cell and metagenomic analysis. PLoS One 6(2):e16626

Campbell JH, Clark JS, Zak JC (2009) PCR-DGGE Comparison of bacterial community structure in fresh and archived soils sampled along a Chihuahuan Desert elevational gradient. Microb Ecol 57(2):261-266

Cao H, Li M, Hong Y, Gu J (2011) Diversity and abundance of ammonia-oxidizing archaea and bacteria in polluted mangrove sediment. Syst Appl Microbiol 34(7):513-523

Chain P, Lamerdin J, Larimer F, Regala W, Lao V, Land M, Hauser L, Hooper A, Klotz M, Norton J, Sayavedra-Soto L, Arciero D, Hommes N, Whittaker M, Arp D (2003) Complete genome sequence of the ammonia-oxidizing bacterium and obligate chemolithoautotroph Nitrosomonas europaea. J Bacteriol 185(9):2759-2773

Chen X, Zhu Y, Xia Y, Shen J, He J (2008) Ammonia-oxidizing archaea: important players in paddy rhizosphere soil? Environ Microbiol 10(8):1978-1987

de la Torre JR, Walker CB, Ingalls AE, Koenneke M, Stahl DA (2008) Cultivation of a thermophilic ammonia oxidizing archaeon synthesizing crenarchaeol. Environ Microbiol 10(3):810-818

Di HJ, Cameron KC, Shen JP, Winefield CS, O'Callaghan M, Bowatte S, He JZ (2009) Nitrification driven by bacteria and not archaea in nitrogen-rich grassland soils. Nat Geosci 2:621-624

Elbert W, Weber B, Burrows S, Steinkamp J, Büdel B, Andreae MO, Pöschl U (2012) Contribution of cryptogamic covers to the global cycles of carbon and nitrogen. Nat Geosci 5(7):459-462

Evans RD, Johansen JR (1999) Microbiotic crusts and ecosystem processes. Crit Rev Plant Sci 18(2):183-225

Fan F, Zhang F, Lu Y (2011) Linking plant identity and interspecific competition to soil nitrogen cycling through ammonia oxidizer communities. Soil Biol Biochem 43(1):46-54

Fernandez-Guerra A, Casamayor EO (2012) Habitat-associated phylogenetic community patterns of microbial ammonia oxidizers. PLoS One 7(10):e47330

Francis CA, Roberts KJ, Beman JM, Santoro AE, Oakley BB (2005) Ubiquity and diversity of ammonia-oxidizing archaea in water columns and sediments of the ocean. Proc Natl Acad Sci USA 102(41):14683-14688

French E, Kozlowski JA, Mukherjee M, Bullerjahn G, Bollmann A (2012) Ecophysiological characterization of ammonia-oxidizing archaea and bacteria from freshwater. Appl Environ Microbiol 78(16):5773-5780

Fu BJ, Zhang QJ, Chen LD, Zhao WW, Gulinck H, Liu GB, Yang QK, Zhu YG (2006) Temporal change in land use and its relationship to slope degree and soil type in a small catchment on the Loess Plateau of China. Catena 65(1):41-48

Garcia-Pichel F, Belnap J (1996) Microenvironments and microscale productivity of cyanobacterial desert crusts. J Phycol 32(5):774-782

Garcia-Pichel F, Lopez-Cortes A, Nubel U (2001) Phylogenetic and morphological diversity of cyanobacteria in soil desert crusts from the Colorado Plateau. Appl Environ Microbiol 67(4):1902-1910

Garcia-Pichel F, Johnson SL, Youngkin D, Belnap J (2003) Small-scale vertical distribution of bacterial biomass and diversity in biological soil crusts from arid lands in the Colorado Plateau. Microb Ecol 46(3):312-321
Garcia-Pichel F, Wojciechowski MF (2009) The evolution of a capacity to build supra-cellular ropes enabled filamentous cyanobacteria to colonize highly erodible substrates. PLoS One 4(11):e7801

Glaser K, Hackl E, Inselsbacher E, Strauss J, Wanek W, Zechmeister-Boltenstern S, Sessitsch A (2010) Dynamics of ammonia-oxidizing communities in barleyplanted bulk soil and rhizosphere following nitrate and ammonium fertilizer amendment. FEMS Microbiol Ecol 74(3):575-591

Gleeson DB, Mueller C, Banerjee S, Ma W, Siciliano SD, Murphy DV (2010) Response of ammonia oxidizing archaea and bacteria to changing water filled pore space. Soil Biol Biochem 42(10):1888-1891

Gubry-Rangin C, Nicol GW, Prosser JI (2010) Archaea rather than bacteria control nitrification in two agricultural acidic soils. FEMS Microbiol Ecol 74(3):566-574

Gubry-Rangin C, Hai B, Quince C, Engel M, Thomson BC, James P, Schloter M, Griffiths Rl, Prosser Jl, Nicol GW (2011) Niche specialization of terrestrial archaeal ammonia oxidizers. Proc Natl Acad Sci USA 108(52):21206-21211

Gundlapally SR, Garcia-Pichel F (2006) The community and phylogenetic diversity of biological soil crusts in the Colorado Plateau studied by molecular fingerprinting and intensive cultivation. Microb Ecol 52(2):345-357

Hallam SJ, Mincer TJ, Schleper C, Preston CM, Roberts K, Richardson PM, DeLong EF (2006) Pathways of carbon assimilation and ammonia oxidation suggested by environmental genomic analyses of marine Crenarchaeota. PLoS Biol 4(4):E95

Hallin S, Jones CM, Schloter M, Philippot L (2009) Relationship between N cycling communities and ecosystem functioning in a 50-year-old fertilization experiment. ISME J 3:597-605

Hammer $\varnothing$, Harper DA, Ryan PD (2001) PAST: paleontological statistics software package for education and data analysis. Palaeontol Electr 4:1-9

Hatzenpichler R (2012) Diversity, physiology, and niche differentiation of ammonia-oxidizing archaea. Appl Environ Microbiol 78(21):7501-7510

Hatzenpichler R, Lebedeva EV, Spieck E, Stoecker K, Richter A, Daims H, Wagner M (2008) A moderately thermophilic ammonia-oxidizing crenarchaeote from a hot spring. Proc Natl Acad Sci USA 105(6):2134-2139

He J, Shen J, Zhang L, Zhu Y, Zheng Y, Xu M, Di H (2007) Quantitative analyses of the abundance and composition of ammonia-oxidizing bacteria and ammonia-oxidizing archaea of a Chinese upland red soil under long-term fertilization practices. Environ Microbiol 9(9):2364-2374

Hocking R (1976) Analysis and selection of variables in linear-regression. Biometrics 32(1):1-49

Johnson SL, Budinoff CR, Belnap J, Garcia-Pichel F (2005) Relevance of ammonium oxidation within biological soil crust communities. Environ Microbiol 7(1):1-12

Johnson SL, Neuer S, Garcia-Pichel F (2007) Export of nitrogenous compounds due to incomplete cycling within biological soil crusts of arid lands. Environ Microbiol 9(3):680-689

Jung J, Yeom J, Kim J, Han J, Lim HS, Park H, Hyun S, Park W (2011) Change in gene abundance in the nitrogen biogeochemical cycle with temperature and nitrogen addition in Antarctic soils. Res Microbiol 162(10):1018-1026

Katoh K, Misawa K, Kuma K, Miyata T (2002) MAFFT: a novel method for rapid multiple sequence alignment based on fast Fourier transform. Nucleic Acids Res 30(14):3059-3066

Kim J, Jung M, Park S, Rijpstra WIC, Damste JSS, Madsen EL, Min D, Kim J, Kim G, Rhee S (2012) Cultivation of a highly enriched ammonia-oxidizing archaeon of thaumarchaeotal group I.1 b from an agricultural soil. Environ Microbiol 14(6):1528-1543

Klappenbach JA, Saxman PR, Cole JR, Schmidt TM (2001) rrndb: the Ribosomal RNA Operon Copy Number Database. Nucleic Acids Res 29(1):181-184

Konneke M, Bernhard AE, de la Torre JR, Walker CB, Waterbury JB, Stahl DA (2005) Isolation of an autotrophic ammonia-oxidizing marine archaeon. Nature 437(7058):543-546

Lehtovirta LE, Prosser JI, Nicol GW (2009) Soil pH regulates the abundance and diversity of Group 1.1c Crenarchaeota. FEMS Microbiol Ecol 70(3):367-376

Lehtovirta-Morley LE, Stoecker K, Vilcinskas A, Prosser JI, Nicol GW (2011) Cultivation of an obligate acidophilic ammonia oxidizer from a nitrifying acid soil. Proc Natl Acad Sci USA 108(38):1-6

Leininger S, Urich T, Schloter M, Schwark L, Qi J, Nicol GW, Prosser Jl, Schuster SC, Schleper C (2006) Archaea predominate among ammonia-oxidizing prokaryotes in soils. Nature 442(7104):806-809

Liu Y, Zheng Y, Shen J, Zhang L, He J (2010) Effects of mercury on the activity and community composition of soil ammonia oxidizers. Environ Sci Pollut Res 17(6):1237-1244 
Mao Y, Yannarell AC, Mackie RI (2011) Changes in N-transforming archaea and bacteria in soil during the establishment of bioenergy crops. PLoS One 6(9):e24750. doi:10.1371/journal.pone.0024750

Martens-Habbena W, Berube PM, Urakawa H, de la Torre JR, Stahl DA (2009) Ammonia oxidation kinetics determine niche separation of nitrifying Archaea and Bacteria. Nature 461(7266):976-979

Marusenko Y, Huber DP, Hall SJ (2013) Fungi mediate nitrous oxide production but not ammonia oxidation in aridland soils of the southwestern US. Soil Biol Biochem 63:24-36.

Matsutani N, Nakagawa T, Nakamura K, Takahashi R, Yoshihara K, Tokuyama T (2011) Enrichment of a novel marine ammonia-oxidizing archaeon obtained from sand of an eelgrass zone. Microb Environ 26(1):23-29

Mosier AC, Francis CA (2008) Relative abundance and diversity of ammoniaoxidizing archaea and bacteria in the San Francisco Bay estuary. Environ Microbiol 10:3002-3016

Mosier AC, Lund MB, Francis CA (2012) Ecophysiology of an ammonia-oxidizing archaeon adapted to low-salinity habitats. Microb Ecol 64(4):955-963

Nagy ML, Perez A, Garcia-Pichel F (2005) The prokaryotic diversity of biological soil crusts in the Sonoran Desert (Organ Pipe Cactus National Monument, AZ). FEMS Microbiol Ecol 54(2):233-245

Nannipieri P, Eldor P (2009) The chemical and functional characterization of soil $\mathrm{N}$ and its biotic components. Soil Biol Biochem 41(12):2357-2369

Nicol GW, Prosser JI (2011) Strategies to determine diversity, growth and activity of ammonia oxidising archaea in soil. Methods Enzymol 496:3-34

Norton JM, Alzerreca JJ, Suwa Y, Klotz MG (2002) Diversity of ammonia monooxygenase operon in autotrophic ammonia-oxidizing bacteria. Arch Microbiol 177(2):139-149

Ochsenreiter T, Selezi D, Quaiser A, Bonch-Osmolovskaya L, Schleper C (2003) Diversity and abundance of Crenarchaeota in terrestrial habitats studied by 16S RNA surveys and real time PCR. Environ Microbiol 5(9):787-797

Palmer MW (1993) Putting things in even better order-the advantages of canonical correspondence-analysis. Ecology 74(8):2215-2230

Park B, Park S, Yoon D, Schouten S, Damste JSS, Rhee S (2010) Cultivation of autotrophic ammonia-oxidizing archaea from marine sediments in coculture with sulfur-oxidizing bacteria. Appl Environ Microbiol 76(22):7575-7587

Pester M, Rattei T, Flechl S, Groengroeft A, Richter A, Overmann J, Reinhold-Hurek B, Loy A, Wagner M (2012) amoA-based consensus phylogeny of ammoniaoxidizing archaea and deep sequencing of amoA genes from soils of four different geographic regions. Environ Microbiol 14(2):525-539

Pointing SB, Belnap J (2012) Microbial colonization and controls in dryland systems. Nat Rev Microbiol 10(8):551-562

Prosser Jl, Nicol GW (2012) Archaeal and bacterial ammonia-oxidisers in soil: the quest for niche specialisation and differentiation. Trends Microbiol 20 (11):523-531

Rotthauwe JH, Witzel KP, Liesack W (1997) The ammonia monooxygenase structural gene amoA as a functional marker: molecular fine-scale analysis of natural ammonia-oxidizing populations. Appl Environ Microbio 63(12):4704-4712

Safriel U, Adeel Z, Niemeijer D, Puigdefabregas J, White R, Lal R, Winslow M, Ziedler J, Prince S, Archer E, King C (2005) Dryland systems. In: Hassan R, Scholes RJ, Ash N (eds) Ecosystems and human well-being. Findings of the Conditions and Trends Working Group of the Millennium Ecosystem Assessment. Island Press, Washington DC, pp 623-662

Santoro AE, Casciotti KL (2011) Enrichment and characterization of ammonia-oxidizing archaea from the open ocean: phylogeny, physiology and stable isotope fractionation. ISME J 5(11):1796-1808

Schimel JP, Bennett J (2004) Nitrogen mineralization: challenges of a changing paradigm. Ecology 85(3):591-602

Schleper C, Nicol GW (2010) Ammonia-oxidising archaea_physiology, ecology and evolution. Adv Microb Physiol 57(57):1-41

Schlesinger WH (1997) Biogeochemistry: an analysis of global change. Academic, San Diego, USA

Shen J, Zhang L, Zhu Y, Zhang J, He J (2008) Abundance and composition of ammonia-oxidizing bacteria and ammonia-oxidizing archaea communities of an alkaline sandy loam. Environ Microbiol 10(6):1601-1611

Smith AC, Koper N, Francis CM, Fahrig L (2009) Confronting collinearity: comparing methods for disentangling the effects of habitat loss and fragmentation. Landscape Ecol 24(10):1271-1285

Soule T, Anderson IJ, Johnson SL, Bates ST, Garcia-Pichel F (2009) Archaeal populations in biological soil crusts from arid lands in North America. Soil Biol Biochem 41(10):2069-2074
Stahl DA, de la Torre JR (2012) Physiology and diversity of ammonia-oxidizing archaea. Annu Rev Microbiol 66:83-101

Strauss SL, Day TA, Garcia-Pichel F (2012) Nitrogen cycling in desert biological soil crusts across biogeographic regions in the Southwestern United States. Biogeochemistry 108(1-3):171-182

Tamura K, Peterson D, Peterson N, Stecher G, Nei M, Kumar S (2011) MEGA5 molecular evolutionary genetics analysis using maximum likelihood, evolutionary distance, and maximum parsimony methods. Mol Biol Evol 28(10):2731-2739

Ter Braak CJF (1986) Canonical correspondence-analysis-a new eigenvector technique for multivariate direct gradient analysis. Ecology 67(5):1167-1179

Tourna M, Freitag TE, Nicol GW, Prosser JI (2008) Growth, activity and temperature responses of ammonia-oxidizing archaea and bacteria in soil microcosms. Environ Microbiol 10(5):1357-1364

Tourna M, Stieglmeier M, Spang A, Koenneke M, Schintlmeister A, Urich T, Engel M, Schloter M, Wagner M, Richter A, Schleper C (2011) Nitrososphaera viennensis, an ammonia oxidizing archaeon from soil. Proc Natl Acad Sci USA 108(20):8420-8425

van der Heijden MGA, Bardgett RD, van Straalen NM (2008) The unseen majority: soil microbes as drivers of plant diversity and productivity in terrestrial ecosystems. Ecol Lett 11(3):296-310

Venter JC, Remington K, Heidelberg JF, Halpern AL, Rusch D, Eisen JA, Wu DY, Paulsen I, Nelson KE, Nelson W, Fouts DE, Levy S, Knap AH, Lomas MW, Nealson K, White O, Peterson J, Hoffman J, Parsons R, Baden-Tillson H, Pfannkoch C, Rogers YH, Smith HO (2004) Environmental genome shotgun sequencing of the Sargasso Sea. Science 304(5667):66-74

Walker CB, de la Torre JR, Klotz MG, Urakawa H, Pinel N, Arp DJ, Brochier-Armanet C, Chain PSG, Chan PP, Gollabgir A, Hemp J, Huegler M, Karr EA, Koenneke M, Shin M, Lawton TJ, Lowe T, Martens-Habbena W, Sayavedra-Soto LA, Lang D, Sievert SM, Rosenzweig AC, Manning G, Stahl DA (2010) Nitrosopumilus maritimus genome reveals unique mechanisms for nitrification and autotrophy in globally distributed marine crenarchaea. Proc Natl Acad Sci USA 107(19):8818-8823

Wall DH, Virginia RA (1999) Controls on soil biodiversity: insights from extreme environments. Appl Soil Ecol 13(2):137-150

Xu M, Schnorr J, Keibler B, Simon HM (2012) Comparative analysis of 165 rRNA and amoA genes from archaea selected with organic and inorganic amendments in enrichment culture. Appl Environ Microbiol 78(7):2137-2146

Ye L, Zhang T (2011) Ammonia-oxidizing bacteria dominates over ammoniaoxidizing archaea in a saline nitrification reactor under low DO and high nitrogen loading. Biotechnol Bioeng 108(11):2544-2552

Zeglin LH, Taylor AE, Myrold DD, Bottomley PJ (2011) Bacterial and archaeal amoA gene distribution covaries with soil nitrification properties across a range of land uses. Environ Microbiol Rep 3(6):717-726

Zhang L, Wang M, Prosser Jl, Zheng Y, He J (2009) Altitude ammonia-oxidizing bacteria and archaea in soils of Mount Everest. FEMS Microbiol Ecol 70(2):52-61

Zhang LM, Offre PR, He JZ, Verhamme DT, Nicol GW, Prosser JI (2010) Autotrophic ammonia oxidation by soil thaumarchaea. Proc Natl Acad Sci USA 107(40):17240-17245

Zhang X, Liu W, Bai Y, Zhang G, Han X (2011) Nitrogen deposition mediates the effects and importance of chance in changing biodiversity. Mol Ecol 20(2):429-438

doi:10.1186/2192-1709-2-9

Cite this article as: Marusenko et al:: Ammonia-oxidizing archaea and bacteria are structured by geography in biological soil crusts across North American arid lands. Ecological Processes 2013 2:9. 